\title{
Developing Learning Media Based on Geographic Information System for Geography Subject in Senior High Schools
}

\author{
Riko Arrasyid1, Iwan Setiawan², Dede Sugandi ${ }^{3}$ \\ 1 rikoarrasyid@upi.edu \\ 1, 2, 3 Departemen Pendidikan Geografi, Universitas Pendidikan Indonesia \\ Submitted \\ July 24, 2018 \\ Revised \\ June 24, 2019 \\ http://dx.doi.org/10.17509/jpis.v28i1.12163
}

\begin{abstract}
This study aims to develop learning media based on Geographic Information Systems (GIS) in Geography subject in high schools. This research was designed to develop space-based geography learning media with various data formats (multimedia). This study uses a quasi-experimental design to examine whether there is an influence of the use of GIS in geography learning. The subjects of the study were social class elevnth graders at SMAN 15 Kota Bandung, Indonesia which is the experimental site as well. The analytical technique used is Kolalogov-Smirnov. Based on the results of the analysis and discussion, it can be concluded that the development of GIS-based geography learning media can be developed as a geography learning media. GIS-based learning media developed showed significant influence on learning achievement of learners.
\end{abstract}

Keywords: development, learning media, Geographic Information System, quasi experiment, learning predetermination

\begin{abstract}
ABSTRAK
Penelitian ini bertujuan untuk mengembangkan media pembelajaran berbasis Sistem Informasi Geografis (SIG) pada mata pelajaran geografi di SMA. Penelitian ini didesain untuk mengembangkan media pembelajaran geografi yang berbasis spasial dengan format data yang beragam (multimedia). Penelitian ini menggunakan desain quasi eksperiment untuk meneliti ada tidaknya pengaruh pemanfaatan SIG dalam pembelajaran geografi. Subjek penelitian yang ditetapkan adalah peserta didik kelas XI IPS di SMAN 15 Kota Bandung sebagai tempat eksperimen. Teknik analisis yang digunakan adalh Kolmogorov-Smirnov. Berdasarkan hasil analisis dan pembahasan, dapat disimpulkan bahwa pengembangan media pembelajaran geografi berbasis SIG dapat dikembangkan sebagai media pembelajaran geografi. Media pemebelajaran berbasis SIG yang dikembangkan menunjukan pengaruhnya yang signifikan terjadi pada prestasi belajar peserta didik.

Kata Kunci: pengembangan, media pembelajaran, Sistem Informasi Geografis, quasi eksperiment, prsetasi belajar
\end{abstract}

\section{INTRODUCTION}

Geography is one of the subjects taughts in schools based on the curriculum in various countries including in Indonesia. It is due to the fact that geography is an important as well as useful subject matter, either in developing or in developed countries [1]. Geography is closely related to the contexts of nationalism, nationality, 
economy, and history. It also gives awareness on the love of homeland and significant contribution to the future world peace in forms of good attitudes, sympathy, tolerance, collaboration, and respect, and encourages students to have solid global awareness so that they will have an ability to think globally [1]. Despite its importance, geography faces a number of obstacles. One of which is that it is considered not interesting [2]. This is becoming a global issue as well since geography tends to have little focus and repetitive learning in such developed countries as the US and UK [3].

The development of information and communication technology (ICT) gives a lot of benefits in enhacing the quality of learning geography. To this relation, Geographic Information System (GIS) as a space-based learning medium can be utilized in understanding numerous geographical phenomena. However, this GIS has not been widely used and developed in Indonesia. In addition, there were few studies discussing the use of GIS, particularly in the context of teaching and learning [4]. The community of geography education researchers are not sure of the GIS substantial contribution towards the teaching and learning processes [5].

In addition to the limited number of studies related to GIS in learning, the availability of a software especially designed for learning is low. In technical terms, the time to apply GIS in learning is considered inadequate, the geographical contents in the GIS database do not fit in the objective of the existing curriculum, and GIS appears to be compex to operate [6]. In the meantime, teachers expect that there is a kind of GIS-based learning kit which is user-friendly and ready to implement [7].
The use of GIS has actually been implemented for education in several countries. In China, for instance, its ministry of education obliges all students to learn the basic concepts and implementatation of GIS. GIS has also been integrated in senior secondary geography curriculum in Hongkong since 2009. Some of other countries have also introduced GIS to their curriculum; some of which are USA, Canada, Australia, Turkey, Japan, Singapore, Malaysia, etc [7].

Although there have been several countries integrating GIS to their curriulum, the implementation is still very limited. There are some obstacles found. In Hongkong, it has been identified that utilizing GIS in the curriculum is not a simple job [7]. Results of previous studies concluded that there are such obstacles in using GIS in schools as lack of knowledge on GIS, limited time develop GIS-based geography curriculum, lack of geography curriculum resources, difficult access to computer laboratories, complex use of GIS technology, absent support of infrastructure and experts, limited number of GIS developing companies providing the modules in accordance with the curriculum, reluctance of teachers to participate on training on GIS, various levels of students' skills and mastery in geographic ICT [7]-[12].

Based on the aforementioned reasons, it is necessary to develop a GISbased application for learning geography. Therefore, learning geography in schools, with the use of GIS based on ICT, is expected to be more interesting.

\section{RESEARCH METHOD \\ Research Design}

This research was designed to develop geographic learning media 
through an experiment. The development was based on the need of space-based learning media with multimedia data format. To meet this need, we created and developed a userfriendly GIS system which was able to diplay data in a variety of formats. The user interface was designed to be simple with such basic facilities as thematic maps, data searching, and data display in various formats.

This study employed an experimental design to investigate whether there is an imapct of the use of GIS as learning media in learning geography, particularly towards students' achievement. Moreover, the experimental design used in this study was a quasi experiment with unequal control groups.

\section{Population and Sample}

The population in this study contained all students at one of the state senior high schools in Bandung, Indonesia, namely SMAN 15 Kota Bandung. Both experimental and group controls in this study were selected from the school. Out of four social classes from eleventh grade in the school, two classes were randomly selected to perform as the groups studied. Social class 2 consisting of 37 students was chosen to be the experimental group and social class 4 consisting of 42 students was determined to be the control group.

\section{Research Variables}

This study adminsitered students' achievement as its dependent variable and the use of GIS learning media as its indepenent variable. Students' achivement was determined by their ability to answer a set of questions related to the subject matters taught. The comparison of students' score before and after learning using GIS would set the effectiveness of the use of GIS in the learning.

\section{Materials}

The learning materials developed in this study referred to the latest curriculum implemented in Indonesia, namely the 2013 curriculum. Specifically, the materials are related to the topic of disaster mitigation which is taught in grade eleven.

\section{Research Instruments and Devices}

The instruments and devices used in this study were grouped into two periods; first was when the application was developed and second was when it was applied for experiment in the school. When implementing the application, we used a handycam and a computer. Meanwhile, the instruments used were classified into test and nontest types. The test was used to measure the knowledge acquired during the lesson. A multiple-choice test was selected to be the testing instrument in this study.

\section{Data Collection Procedure}

Spatial data used in developing GIS were obtained from several resources, both primary and secondary ones. The procedure of the data collection is explained as follows.

1. Identifying the needs of the curriculum

2. Selecting the basic contents to be developed

3. Exploring the existing secondary data needed

4. Collecting secondary data from related institutions

5. Collecting primary data in the field

6. Selecting data to be used from the data collected 
7. Inputing the data into the GIS In the meantime, the procedure of the application trial consisted of preparation, implementaion, and data analysis. The preparation comprised activities of permit application to the school, research instrument arrangement, and research instrument trial. The implementation included pretest, the lesson, and post-test. Finally, data analysis was done when every step of the procedure was finished.

\section{Application Development}

The application used to develop GIS desktop was arcgis online template. The next step was then creating the appilcation development line concepts based on the needed functions consisting of initial preparation of choosing the application model, preparation of devices, preparation of materials, application design, and finishing process which was implemeting the GIS-based learning media in the school.

\section{Analysis of Experimental Results}

Analysis of experimental results were employed to measure the influence of the use of GIS towards students' learning achivement. Posttest was administered to both of the groups. In addition, statistical analysis was also performed to identify the significance of differences between the experimental and control groups. To meet the need, a non-parametric Kolmogorov Smirnov Z-test was applied considering that the data were not normally distributed.

\section{RESULTS AND DISCUSSION}

The Plot of the Application
Development

1. Determining the GIS Media
Application Model

The purpose of this activity is to come up with the model to be developed and the purpose of developing the media is to help teachers and students in learning geography. Morevoer, it is expecte4d that the teachers can provide spatial data according to the curriculum and the students can searh the data to solve problems as the learning used problembased learning model. It has been revealed that teachers and students have difficulties in operating GIS; therefore, the main consideration of creating the GIS model is its applicability and user-friendliness for both teachers and students. Another consideration of choosing the right model is the limited time of the lesson which demands the application to be able to be operated fast.

\section{Developing GIS through ArcGIS Online}

The development of the application contains a series of detailed processes. The first process is prepating the tools needed. In this process, the tools needed are both ArcGIS Dekstop and ArcGIS Online softwares. The next process is preparing the materials needed. The materials in this study are a set of database serving as secondary data. Map database is computer data with georeferences. The database format is Shapefile which is archived in ZIP, CSV and TXT files with optional addresses and lattitude and longitude (separeted by a comma, a semi collon, or a tab), and GPX files (GPX exchange format).

The secondary data mostly contain attributive infromation, texts, videos, graphics, and figures which will be related to the map database. All the data are input in the data upload process through ArcGIS online. The next process, which is desgining the GIS

4 Riko Arrasyid, dkk. | Developing Learning Media... 
media, connects the designed media to the implementation. This process plays an important role since the development of the GIS application media starts and restarts from this process.

\section{Testing the Application}

The process results in revised editions of the application during the development process. The initial testing of the application is this study is conducted in the school within the preexperimental period. After the initial test, there is feedback which will be useful for the development of the application.

\section{Interface Design of the GIS Media Application}

Based on the plot of the application development processes, it is found that the interface design of the application shoul enable users to display maps, videos, and attributive data so that the frames available are the map frame, the selected layer, photos/ videos/ films, and a frame to present attributive data and info. The results of the design development of the application are shown in Figure 1.

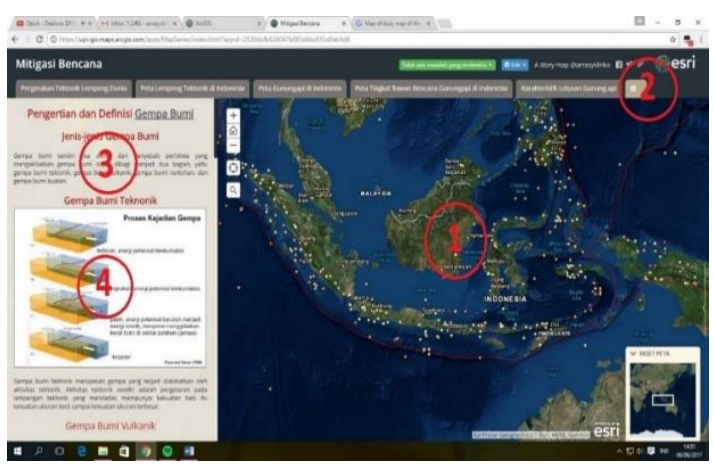

Source: Authors, 2017

Figure 1. User Interface of GIS Learning Media Application for Geography Learning on Disaster Mitigation

Remarks:

1. The window to present maps
2. The window to display layers and windows

3. The window to display photos

4. The window to display videos and pictures

\section{The Influence of GIS towards students' learning achievement}

To measure students' learning achievement, we used 50 multiplechoice questions as the testing instrument. The questions were made based on Bloom's Taxonomy which includes not only cognitive aspect but other important aspects as well. Prior to hypothesis testing of the influence of the use of GIS towards students' learning achievement, we conducted a set of prerequisite tests. Based on the normality test, it has been found that the data of either the experiemental or the control group are not normally distributed. The results of the test are presented in Table 1.

Tabel 1. Results of the Data Normality

Test for Experimental and Control Groups

\begin{tabular}{lccc}
\hline \multicolumn{1}{c}{ Data } & $\begin{array}{c}\text { Probabilty } \\
\text { (Sig. 2- } \\
\text { tailed) }\end{array}$ & a & Conclusion \\
\hline $\begin{array}{l}\text { Experimental } \\
\text { Group }\end{array}$ & 0.000 & 0.05 & abnormal \\
\hline $\begin{array}{l}\text { Control } \\
\text { Group }\end{array}$ & 0.000 & 0.05 & abnormal \\
\hline
\end{tabular}

Source: Results of this study, 2017

Since the normality assumption on the prerequisite test was not fuilfilled for parametric statistics, we do the hypotehsis testing using non-parametric statstics. The proposed hypothesis is that there is an influence of the user of SIG as learning media and a learning resource towards students' learning achievement.

The statistical analysis is conducted using non-parametric Kolmogorov-Smirnov. The results show that there is a significant difference 
between the experimental group and the control group. However, the results cannot show which group has the higher average score as shown in Table 2.

Table 2. The Analytical Results of Kolmogorov-Smirnov Test

\begin{tabular}{lcc}
\hline & Test Score \\
\hline $\begin{array}{l}\text { Most Extreme } \\
\text { Differences } \\
\text { Absolute }\end{array}$ & .513 \\
\hline \multicolumn{2}{c}{ Positive } & .513 \\
\hline \multicolumn{2}{c}{ Negative } & .00 \\
\hline $\begin{array}{l}\text { Kolmogrov- } \\
\text { Smirnov Z }\end{array}$ & 2.126 \\
\hline Asymp. Sig. (2-tailed) & .000 \\
\hline \multicolumn{2}{c}{ Sourcer: Results of this study, 2017 }
\end{tabular}

\section{CONCLUSION}

GIS is an application which can be developed as a learning medium in geography displaying spatial data in a variety of formats. It has been revealed that to contribute to students' learning achievement implied by the different mean score of two groups studied.

\section{RECOMMENDATION}

It is expected that GIS is constantly developed considering its effectiveness in improving students' learning achievement. The development can be in local, national, and even international scales so that it can meet various demands, including the existing curriculum.

Table 3. Statistical Description of the Experimental and Control Groups

\begin{tabular}{lcccccc}
\hline & N & Min & Max & Mean & Std. Deviation & Variance \\
\hline Control Group & 42 & 10.00 & 23.00 & 23.3333 & 2.78733 & 7.769 \\
\hline $\begin{array}{l}\text { Experimental } \\
\text { Group }\end{array}$ & 37 & 21.00 & 32.00 & 27.6538 & 2.33139 & 5.435 \\
\hline Valid N (listwise) & 37 & & & & & \\
\hline
\end{tabular}

Source: Results of this study, 2017

It has been revealed that the average score of the experimental group is higher than that of the control group (see Table 3). This indicates that the experimental group, supported with the use of GIS in learning geography, outperforms the control group.

In addition to the learning contents, GIS-based media should also focus on utilizing ICT which develops rapidly. Multimedia information on spatial data is such a great contribution to make learning more interesting and attractive. The application is also proven to be able to enhance the effectiveness and efficiency of the learning since it serves as a learning medium conveying necessary information and also a center of attention possibly enhancing students' learning achievement.
Finally, the development should also be in accordance with the location the application is used so that learning will be relevant.

\section{REFERENCES}

[1] D. Mansfild, "The Importance of Geography in the School Curriculum." National Council for Geographic Education, 16A Leonard Hall, Indiana University of Pennsylvania, Indiana, PA 157051087., 1994.

[2] E. Maryani, "Geografi dalam Pendidikan di Persekolahan," in Ilmu Pendidikan, Bandung, 2006.

[3] E. Rawling, "Connecting policy and practice: Research in geography education," Br. Educ. Res. J., 2003.

[4] S. Liu and X. Zhu, "Designing a Structured and Interactive Perspektif Keilmuan dan 
Learning Environment Based on GIS for Secondary Geography Education," J. Geog., vol. 107, no. 1, pp. 12-19, May 2008.

[5] S. W. Bednarz, "Geographic Information Systems: A Tool to Support Geography and Environmental Education?," GeoJournal, vol. 60, no. 2, pp. 191199, 2004.

[6] T. T. Favier and J. A. van der Schee, "Exploring the characteristics of an optimal design for inquirybased geography education with Geographic Information Systems," Comput. Educ., vol. 58, no. 1, pp. 666-677, Jan. 2012.

[7] C.-C. Lam, E. Lai, and J. Wong, "Implementation of geographic information system (GIS) in secondary geography curriculum in Hong Kong: current situations and future directions," Int. Res. Geogr. Environ. Educ., vol.18, no. 1, pp. 57-74, Mar. 2009.

[8] M. Marsh, R. Golledge, and S. E. Battersby, "Geospatial Concept Understanding and Recognition in
G6-College Students: A Preliminary Argument for Minimal GIS," Ann. Assoc. Am. Geogr., vol. 97, no. 4, pp. 696-712, Dec. 2007.

[9] P. Wheeler, L. Gordon-Brown, J. Peterson, and M. Ward, "Geographical information systems in Victorian secondary schools: current constraints and opportunities," Int. Res. Geogr. Environ. Educ., vol. 19, no. 2, pp. 155-170, Jun. 2010.

[10] E. O'Dea, “Integrating GIS into Secondary Science Education: An ArclMS Approach," 2002.

[11] L. Y. Yap, G. C. Ivy Tan, X. Zhu, and M. C. Wettasinghe, "An Assessment of the Use of Geographical Information Systems (GIS) in Teaching Geography in Singapore Schools," J. Geog., vol. 107, no. 2, pp. 52-60, Jul. 2008.

[12] R. E. Mayer, "Multimedia learning," Psychol. Learn. Motiv., vol. 41, pp. 85-139, Jan. 2002. 